\title{
The Charter Revolution: IS IT UNDEMOCRATIC?
}

Peter W. Hogg

\section{INTRODUCTION}

A new book on the Canadian Charter of Rights and Freedoms by two professors from the University of Calgary, F.L. Morton and Rainer Knopff, is entitled The Charter Revolution and the Court Party. ${ }^{1}$ By the "Charter revolution" the authors refer to the active lawmaking role assumed by the Supreme Court of Canada since the adoption of the Charter of Rights in $1982 .{ }^{2}$ By the "Court Party" they refer to a cluster of interest groups promoting Charter rights through litigation. ${ }^{3}$ The thesis of the book is that these groups have been successful in obtaining changes in the law from the Supreme Court of Canada that could not have been achieved in the representative legislative assemblies. That, they argue, is wrong because it is "undemocratic.",

I agree that there has been a Charter revolution. I also agree that there is a Court Party, but I will argue that the cluster of interest groups using litigation as their strategy is much broader than the authors acknowledge. I also agree that the effects of these two phenomena have not been wholly beneficial, but I argue that, on the whole, the result is one that enhances rather than usurps a democratic dialogue.

\section{The ChARTER Revolution}

Let me first acknowledge that there has been a "Charter revolution." There is no doubt that the Charter of Rights and Freedoms has been given a much more expansive interpretation than the old Canadian

F.L. Morton \& R. Knopff, The Charter Revolution and the Court Party (Peterborough: Broadview Press, 2000). The book is reviewed in L. Sossin, "Courting the Right" (2000) 38 Osgoode Hall L.J. 531.

2 Canadian Charter of Rights and Freedoms, Part I of the Constitution Act, 1982, being Schedule B to the Canada Act 1982 (U.K.), 1982, c. 11.

Morton \& Knopff, supra note 1 at 24-32.

Ibid. at 149 .
Bill of Rights, ${ }^{5}$ even when the language of the two instruments is the same. ${ }^{6}$ In the criminal justice area, where the majority of Charter cases have come from, the rights have been interpreted more broadly than their equivalents in the United States, even under the Warren court. $^{7}$

Moreover, the Supreme Court of Canada has not adhered to those counsels of procedural restraint that Alexander Bickel famously described as the "passive virtues." ${ }^{\prime}$ The Court has developed no doctrine of ripeness $;{ }^{9}$ mootness rarely defeats proceedings $;{ }^{10}$ lack of standing also rarely defeats proceedings (because of generous discretionary public interest standing); ${ }^{11}$ public interest intervenors are often admitted to appeals (even when they are antagonistic to a criminal defendant) ${ }^{12}$ statutes are occasionally struck down on the basis of hypothetical facts that bear no resemblance to the facts before the Court $;{ }^{13}$ sweeping constitutional rulings are occasionally issued in obiter dicta $;{ }^{14}$ and

Canadian Bill of Rights, S.C. 1960, c. 44, reprinted in R.S.C. 1985, App. III.

6 P.W. Hogg, Constitutional Law of Canada, $4^{\text {th }}$ ed. (Toronto: Carswell, 1997) c. 32, describes the decisions rendered under the Canadian Bill of Rights and contrasts the interpretation given to the Charter of Rights and Freedoms.

R. Harvie \& H. Foster, "Ties that Bind? The Supreme Court of Canada, American Jurisprudence, and the Revision of Canadian Criminal Law under the Charter" (1990) 28 Osgoode Hall L.J. 729; and "Different Drummers, Different Drums: The Supreme Court of Canada, American Jurisprudence and the Continuing Revision of Criminal Law under the Charter" (1992) 24 Ottawa L.Rev. 39.

8 A. Bickel, The Least Dangerous Branch, $2 \mathrm{~d}$ ed. (New Haven: Yale University Press, 1986) c. 4. Whether the passive virtues are indeed virtues is, of course, disputed by those who favour a less restrained role for the courts than did Bickel.

Hogg, supra note 6 at s. 56.4.

$10 \quad$ Ibid. at s. 56.3 .

11 Ibid. at s. 56.2(d).

12 Ibid. at s. 56.6.

13 See e.g. R. v. Smith, [1987] 1 S.C.R. 1045 (striking down minimum sentence for importing drugs); R.v. Heywood, [1994] 3 S.C.R. 761 (striking down prohibition of previously convicted sexual offenders from loitering in playgrounds).

14 See e.g. R. v. Brydges, [1990] 1 S.C.R. 190 at para. 27 (instructing police officers to warn arrested persons of the availability of free duty counsel and legal aid); Delgamuukw v. 
statutes are occasionally directly amended by the Court simply "severing" words that create a constitutional defect or even "reading in" new language that would cure the constitutional defect. ${ }^{15}$

In a study published in 1997, Allison Bushell (now Thornton) and I found sixty-five cases in which the courts had struck down or directly amended a federal or provincial law under the Charter of Rights since its adoption in $1982,{ }^{16}$ and there are many more cases in which the actions of police officers or government officials have been annulled. This is certainly a "Charter revolution."

\section{THE COURT PARTY}

Morton and Knopff, as political scientists, are interested in how the enhanced law-making power of the Supreme Court of Canada affects political behaviour. They use the expression "the Court Party" to encompass a cluster of interest groups promoting rights, and they point out that these groups have adapted to the Charter revolution by looking to the courts to advance their policy objectives. The groups they identify include feminist groups, gay and lesbian groups, poverty activists, as well as more traditional civil libertarians promoting freedom of expression, freedom of religion and fairness in the criminal justice system. ${ }^{17}$ These actors, it is argued, have succeeded in persuading the Court to adopt unpopular left-wing causes that could not survive the public scrutiny that is characteristic of democratic decision-making. ${ }^{18}$

However, the policy objectives of the groups that comprise the "Court Party" are not always consistent with each other, and they sometimes find themselves on opposite sides of a Charter case, as has occurred, for example, in cases involving hate propaganda, ${ }^{19}$ pornography, ${ }^{20}$ and rape-shield laws. ${ }^{21}$ The expression "the Court Party" is misleading in its suggestion of a monolithic movement with the same objectives. What the members of the so-called Court Party have in

B.C., [1997] 3 S.C.R. 1010 at paras. 165-69(defining aboriginal title).

15 Hogg, supra note 6 at ss. 37.1(e) and (f) provide examples of severance and reading in.

16 P.W. Hogg \& A.A. Bushell, "The Charter Dialogue Between Courts and Legislatures" (1997) 35 Osgoode Hall L.J. 75 at 81

Morton \& Knopff, supra note 1 at c. 3 .

$18 \quad$ Ibid. at 59.

19 R. v. Keegstra, [1990] 3 S.C.R. 697; R. v. Zundel, [1992] 2 S.C.R. 731; Ross v. New Brunswick School District No. 15 [1996] 1 S.C.R. 825 .

${ }^{20} \quad$ R. v. Butler, [1992] 1 S.C.R. 452; Little Sisters Book and Art Emporium v. Canada, [2000] 2 S.C.R. 1120; R. v. Sharpe, [2001] 1 S.C.R. 45

${ }^{21}$ R. v. Seaboyer, [1991] 2 S.C.R. 577; R. v. Mills, [1999] 3 S.C.R. 668 common is an interest in supporting the power of judicial review under the Charter, because that power is often the means by which they can attain policy objectives that are not attainable in the elected legislatures.

In the sense used by Morton and Knopff, there has always been a "Court Party." 22 The term could easily be used for business groups that resist the regulation imposed on them by elected legislative bodies. ${ }^{23}$ They have historically used judicial review to rewin policy battles lost in the elected legislative bodies. As J.R. Mallory pointed out fifty years ago, the force that drives constitutional litigation has typically been "the reaction of a free economy against regulation." ${ }^{24}$ The most famous examples of the reaction of a free economy are the cases decided in the Lochner era (1905-1937) in the United States, where rights to liberty, property and due process were used by the Supreme Court of the United States to defeat legislation imposing fairer employment conditions on business and protecting trade unions. ${ }^{25}$

While the extreme laissez-faire interpretations of the American Bill of Rights ended in 1937, business corporations are still a major source of constitutional litigation in the United States as well as in Canada. In Canada, before the adoption of the Charter in 1982, business corporations used the division of powers provisions of the Constitution to challenge government regulation. ${ }^{26}$ Since the adoption of the Charter, business corporations have used Charter litigation to challenge a variety of regulatory laws, for example, the prohibition on Sunday shopping, ${ }^{27}$ restrictions on

\footnotetext{
This is recognized by Morton and Knopff, supra note 1 at c. 3 .

23 Sossin, supra note 4 at 541, comments that "The Court Party, if it includes groups which seek to use the courtroom to further a policy agenda, constitutes a big tent indeed, with gay and lesbian activists alongside tobacco executives, and LEAF [Women's Legal Education and Action Fund] shoulder to shoulder with the NCC [National Citizens' Coalition]."

24 J.R. Mallory, "The Courts and the Sovereignty of the Canadian Parliament" (1944) 10 Can. J. Economics \& Poli. Sci. 169; quoted in Morton \& Knopff, supra note 1 at 64.

25 The story is briefly related in Hogg, supra note 6 at s. 33.4(b).

26 See e.g. the cases challenging food and drug standards (Hogg, supra note 6 at s. 18.3), regulation of anti-competitive behaviour (ibid. at s. 18.6), Sunday observance laws (ibid at s. 18.7), movie censorship (ibid. at s. 18.11), regulation of the insurance industry (ibid. at s. 21.5), regulation of labour relations and standards (ibid. at s. 21.8), regulation of agricultural marketing schemes (ibid. at s. 21.9) and regulation of cable television (ibid. at s. 22.13(c)).

27 R.v.Big M Drug Mart, [1985] 1 S.C.R. 295 (law struck down); R. v. Edwards Books and Art, [1986] 2 S.C.R. 713 (law upheld).
} 
advertising, ${ }^{28}$ and the enforcement provisions of competition law. ${ }^{29}$

Moreover, trade unions are also arguably members of the Court Party, since they too have traditionally turned to the courts to accomplish objectives that cannot be accomplished elsewhere. However, under the Charter, trade union challenges to restrictions on collective bargaining have been uniformly unsuccessful. ${ }^{30}$ This is part of the evidence offered by Michael Mandel, ${ }^{31}$ (among others) ${ }^{32}$ for his argument that the "legalization of politics" under the Charter is not only undemocratic, but a powerful reinforcement of business and other vested interests. Any gains for the disadvantaged, he argues, are more than made up for by the gains to the advantaged. The outcomes produced by representative legislative bodies would on the whole produce more progressive results. Mandel's argument is interesting, because it is virtually the same as that of Morton and Knopff, but comes from an opposite ideological standpoint. Mandel's "Court Party" is the business corporations and the cluster of interest groups that support business objectives.

The "Court Party" identified by Morton and Knopff is quite unlike the business groups identified by Mandel or indeed any groups motivated by their own direct self-interest or that of their members. The Morton-Knopff Court Party pursues what some political scientists have called "postmaterialist" issues. These are not issues that directly serve the economic self-interest of their members (as manufacturers' associations or trade unions would do, for example), but are rather general issues such as the promotion of freedom of expression and religion, education for language minorities, equality for women, gay and lesbian people and racial minorities, and criminal law reform. They are not business issues, and the activities

28 Irwin Toy v. Quebec, [1989] 1 S.C.R. 927 (law prohibiting advertising directed at children upheld); Rocket v. Royal College of Dental Surgeons, [1990] 2 S.C.R. 232 (restrictions on advertising by dentists struck down); RJR-MacDonald $\mathrm{v}$. Canada, [1995] 3 S.C.R. 199 (restrictions on advertising of tobacco products struck down).

29 Hunter v. Southam, [1984] 2 S.C.R. 145 (law struck down).

30 Re Public Service Employees Relations Act (Alberta), [1987] 1 S.C.R. 313; PSAC v. Canada, [1987] 1 S.C.R. 424; Professional Institute v. Northern Territories, [1990] 2 S.C.R. 367; RWDSU v. Saskatchewan, [1987] 1 S.C.R. 460; Professional Institute v. Northwest Territories, [1990] 2 S.C.R. 367; ILWU v. Canada, [1994] 1 S.C.R. 150.

31 M. Mandel, The Charter of Rights and the Legalization of Politics in Canada, rev. ed. (Toronto: Thompson Educational Publishing, 1994).

32 See $e . g$. J.A. Fudge \& H.J. Glasbeek, "The Politics of Rights: A Politics With Little Class" (1992) 1 Social and Legal Studies 45; A.C. Hutchinson, Waiting for CORAF: A Critique of Law and Rights (Toronto: University of Toronto Press, 1995); J. Bakan, Just Words: Constitutional Rights and Social Wrongs (Toronto: University of Toronto Press, 1997). of these postmaterialist groups cannot be characterized as the reaction of a free economy against regulation. Nor are they for the most part working class issues, although improving the lot of the disadvantaged is often a goal of postmaterialist Charter litigation. Support for the postmaterialist issues comes from an intellectual class of academics, students, professionals, journalists and civil servants. The values that they promote are held much more strongly by intellectuals than by the general public, which makes the anti-majoritarian power of the courts attractive. ${ }^{33}$

One would expect postmaterialist groups to be weak, because their goals are public and do not directly benefit their members. Because of the lack of selfish incentives for membership, it is hard to obtain adequate resources simply through membership dues. What is needed is a patron to supply funding. Morton and Knopff show that, to a remarkable extent, that patron has been the government, usually the federal government. Secretary of State funding has been provided to native groups, official language minority groups, multicultural groups and women's groups. The federal Court challenges programme, which was cancelled by the Progressive Conservative government in 1992 but revived by the Liberal government in 1995 , supports Charter litigation. ${ }^{34}$

Why would government want to support groups that are challenging existing government policies and laws? The authors do not dodge this difficult question. They point out that in some cases, for example, official language minorities, the group's policies are consonant with federal public policies in favour of bilingualism and national unity. In some cases, there are already public programmes in place and public officials see value in organized constituents who work to promote and expand the programmes from outside government. ${ }^{35}$ What the authors do not point out is that politicians would not continue to authorize these expenditures of public funds unless there was public support for assistance to rights-seeking groups.$^{36}$ There is indeed that support, which is not surprising considering the stability of public support for the Charter and for judicial review. ${ }^{37}$ As I will argue in the next two sections of this paper, public notions of democracy are not at all offended by judicial review, and the efforts of the Court Party should be seen as, not merely addressed to courts, but as contributions to a

\footnotetext{
Morton \& Knopff, supra note 1 at 78-79.

${ }^{34}$ See e.g. I. Brodie, "The Court Challenges Program" in Law, Politics and the Judicial Process in Canada, F.L. Morton, ed., (Calgary: University of Calgary Press, 1992) 251.

35 Morton \& Knopff, supra note 1 at c. 4.

36 Sossin, supra note 4 at 537.

7 See infra notes 44,45 and accompanying text.
} 
dialogue about rights that engages the public and the legislative bodies no less than the courts.

My conclusion is that the phenomenon of a "Court Party" is not a new one, and indeed the Morton-Knopff postmaterialist Court Party (despite frequent aid by government) lacks the resources and incentives of the business Court Party and on some issues is a counterweight to the business Court Party. In the end, any group has to persuade the Supreme Court of Canada of the rightness of its views in the context of a case in which the other side is also fully argued often with help from another member of one of the Court Parties. While no one would doubt the influence on the Supreme Court of Canada's Charter decisions of the intervenor briefs by LEAF and the Canadian Civil Liberties Association (for example), it is not as if the postmaterialist groups have the field to themselves, and it seems likely that their views have resonated with our political and legal traditions and have influenced public opinion and legislative action as well as the decisions of courts.

\section{DEMOCRACY AND CIVIL LIBERTIES}

Morton and Knopff are opposed to both the Court Party and the Charter revolution, which they describe as "fundamentally undemocratic, not just in the simple and obvious sense of being anti-majoritarian, but also in the more serious sense of eroding the habits and temperament of representative democracy." ${ }^{38}$ They complain that public policies are set by courts, not by representative majorities; that rights claimants are not prepared to accept the judgment of representative majorities; and that political discourse becomes inflated and intolerant when it is framed in the language of rights.

The issues to which the authors regularly return for their examples are women's rights, including the issue of abortion, gay and lesbian rights, minority official language rights and the rights of criminal defendants. ${ }^{39}$ Discussion of these issues is usually framed in the language of rights, because it is difficult for the groups pressing these issues to assemble majorities for their positions in the representative assemblies. They point to the Charter because it does contain guarantees of liberty, security of the person, fair trial, minority language rights and equality. Admittedly the language is vague, and admittedly there is room for conflict among the rights. But it was clearly understood from the inception of the Charter that the scope of the rights would have to be determined by the courts, and that

Morton \& Knopff, supra note 1 at 149 See ibid. at c. 4 . once a court has determined that a claim is properly based on a guaranteed right that claim would have to trump competing public policies unless there was a particularly strong justification for the limitation of the right (another issue expressly remitted to the courts).

It would be foolish to claim that there is no disadvantage to judicial review under an entrenched Charter of Rights. The increased influence of courts and lawyers in the public policy process is a matter that the authors are right to be concerned about. But are they right to see the outcomes as undemocratic? What are the elements of a flourishing democracy? Obviously, the most important elements have to do with effective public participation in setting public policy. Free elections with universal adult suffrage are the foundation, of course, and these must be supported by competing political parties and by freedom of expression, including freedom of the press. But most people would add that the fair treatment of individuals and minorities is also characteristic of a flourishing democracy. At a minimum, that requires an independent legal profession and an independent judiciary, so that the rule of law, binding on governments as well as powerful private parties, is a reality.

Does the fair treatment of individuals and minorities also require guaranteed rights enforced by judicial review? That is a question on which reasonable people differ. Probably the answer is no, since Canada before 1982 was clearly a flourishing democracy respectful of rights despite the absence of an entrenched Charter. Moreover, the policy tools and resources available to legislatures are vastly superior to those of courts, and many important protections of rights have been, and could only be, the creation of legislatures. Labour standards, labour relations laws, human rights codes, employment equity and pay equity come to mind.

But it is undeniable that, in a system of unfettered parliamentary supremacy, it is possible for the majority to enact rules that treat individuals or minorities unfairly. The issues that engage Morton and Knopff are good examples. The feminist literature has shown that many of our legal rules, even those that are genderneutral in form, operate to the disadvantage of women. Women are not a minority, but they are not proportionately represented in the legislative assemblies, and there has been a tendency, at least in the past, for their interests to be ignored or overruled. The same comment applies in spades to the gay and lesbian community. The fact is that discrimination on the basis of sex, sexual orientation, race, national origin and other improper bases has not been eliminated from our legal system. It is also a notorious fact that 
representative assemblies are very sympathetic to the victims of crime and to the efforts of the police and courts to control crime, and there are continuous political pressures to reduce the restraints on police investigative techniques, to erode the right to full answer and defence, and to make penalties and conditions of imprisonment harsher. Needless to say, those accused of criminal behaviour find little support or sympathy in representative assemblies.

The idea that there are rights that should not be subject to legislative repeal simply by an appeal to the general welfare is widely accepted as consistent with or even essential to a democratic polity. It will be recalled that that is the thesis of Professor Ronald Dworkin's famous article, "Taking Rights Seriously." "40 John Hart Ely took Dworkin's idea a step further, arguing that constitutionally guaranteed rights actually reinforce the democratic process by making up for deficiencies in the composition of the legislative assemblies. On this theory, the Charter rights provide support for vulnerable groups ("discrete and insular minorities") who are not properly represented in the democratic process. $^{41}$

These theoretical ideas seem to be supported by the legislative history of the Charter. Its adoption in 1982 was the product of a widespread public debate, in which the inevitable risks of judicial review played a prominent role. Admittedly, the Charter was never put to and approved by a popular referendum, but it has always commanded widespread popular support. A poll taken in 1999, on the heels of two controversial Charter decisions by the Supreme Court of Canada, showed eighty-two per cent of those polled saying that the Charter was "a good thing," and sixty-one per cent saying that the courts, not the legislatures, should have the last word when the courts decide that a law is unconstitutional. ${ }^{42}$ These high levels of support for the

40 R. Dworkin, Taking Rights Seriously (London: Duckworth, 1979) c. 7, originally published as R. Dworkin, "Taking Rights Seriously" (1970) 15:11 New York Review of Books 23.

${ }^{41}$ J.H. Ely, Democracy and Distrust (Cambridge: Harvard University Press, 1982). The same idea has been applied to the Canadian Charter by H.S. Fairley, "Enforcing the Charter: Some Thoughts on an Appropriate and Just Standard of Judicial Review" (1982) 4 Supreme Court L.R. 217; and P.J. Monahan, "Judicial Review and Democracy: A Theory of Judicial Review" (1987) 21 U.B.C.L.Rev. 87

42 J.F. Fletcher \& P. Howe, "Canadian Attitudes towards the Charter and the Courts in Comparative Perspective" (2000) 6:3 Choices 4; "Supreme Court Cases and Court Support: The State of Canadian Public Opinion" (2000) 6:3 Choices 30. The surveys were taken after the decisions in R. v. Feeney, [1997] 2 S.C.R. 13 (excluding reliable evidence of a gruesome murder on the basis that the police had entered the accused's home without a warrant) and Vriend v. Alberta, [1998] 1 S.C.R. 493 (adding sexual orientation as a prohibited ground of discrimination in Alberta's human rights legislation). Both
Charter and for the powers of the Supreme Court of Canada have remained fairly stable over the years since the Charter was adopted. ${ }^{43}$ As noted earlier, these levels of support have not escaped the notice of elected politicians who provide funding for groups to bring Charter litigation. ${ }^{44}$

I conclude that it is an impoverished definition of democracy that makes no provision for a Charter of Rights or for judicial review. Under most understandings of democracy, both those of intellectuals like Dworkin and Ely and those of ordinary people who respond to opinion polls, there is room for judicial review under a Charter of Rights.

\section{DiALOGUE}

The compatibility of the Charter with democracy is reinforced by the notion of judicial review as a "dialogue" between the Supreme Court of Canada and the legislatures. Most writing about the Charter falls into the trap of assuming that, when the Supreme Court of Canada strikes down a law, the Court's decision is the last word on the topic. But this is to view the Charter through an American lens. Everyone remembers President Franklin Roosevelt's desperate (and ultimately unnecessary) plan to "pack" the Supreme Court of the United States in order to salvage the New Deal from the depredations of the Court. ${ }^{45}$ More recent controversies in the United States over the rights of criminal accuseds, flag-burning, pornography, abortion and capital punishment all proceed on the basis that nothing can be done about the decisions of the Supreme Court except to amend the constitution (normally a forlorn hope) or to use the appointment power to gradually change the composition of the Court and hope for more popular results (a highly speculative endeavour).

Canada's Charter contains two features that have no counterparts in the American Bill of Rights: section 1 and section 33. Section 1, which was borrowed from international human rights charters,${ }^{46}$ permits a Charter right to be limited by the competent legislative body, provided the limitation "can be demonstrably justified in a free and democratic society." Section 33, which is an indigenous Canadian invention (since borrowed by

decisions led to considerable public criticism of the Supreme Court of Canada and of the power of judicial review.

43 The study referred to in the previous note compared answers given in 1987 with those given in 1999, finding similar levels of support (ibid. at 5-14).

44 See supra note 34 and accompanying text.

45 D. O'Brien, Storm Center: The Supreme Court in American Politics (New York: Norton, 1986) at 67.

46 See Hogg, supra note 6 at c. 35.1 for elaboration. 
Israel $^{47}$ ), permits a Charter right to be overridden by the competent legislative body, provided the legislation explicitly announces that it is to operate notwithstanding the Charter right. These two provisions are important structural differences between the Canadian Charter and the American Bill of Rights. Their purpose is to give a much stronger role to the representative assemblies on rights issues than is allowed by the Constitution of the United States. Sections 1 and 33 can be seen as a typically Canadian compromise between the American model of judicial review and the English model of parliamentary sovereignty.

In 1997, Bushell and I looked at the sequels to all the cases in which laws had been struck down by the Supreme Court of Canada for violation of the Charter. ${ }^{48}$ We found that the competent legislative body did not usually let matters rest with the decision of the Court. In two cases, the Court's ruling was effectively reversed by the legislature, once by invoking section $1^{49}$ and once by invoking section $33 .^{50}$ In the majority of cases, the Court's ruling was followed by new legislation that accomplished the same legislative objective but with some new civil libertarian safeguards to accommodate the Court's ruling. This pattern, which is fully documented in the footnoted article, led us to describe the relationship between the Court and the legislatures as a "dialogue" - meaning by that term to indicate that sections 1 and 33 of the Charter (among other features) usually allow room for a legislative reaction to a Court decision, and a legislative reaction is indeed usually forthcoming.

This idea of a dialogue between courts and legislatures is a serious challenge to the Morton-Knopff thesis. If Charter decisions are ultimately reviewable by elected legislative bodies, using the distinctively Canadian vehicles of sections 1 or 33 , then it becomes much less significant whether the decisions have been achieved through the efforts of the Court Party or have been made in disregard of popular sentiment. In the last few pages of the book, the authors grapple with this problem. Professors Morton and Knopff acknowledge that the dialogue theory is "undoubtedly true in the

47 See Z. Segal, "The Israeli Constitutional Revolution: The Canadian Impact in the Midst of a Formative Period" (1997) 8:3 Constitutional Forum 53.

48 Hogg \& Bushell, supra note 16.

49 Following the Supreme Court's ruling in R. v. Daviault, [1994] 3 S.C.R. 63, Parliament enacted an amendment to the Criminal Code, making self-induced intoxication no defence to a crime of general intent.

50 Following the Supreme Court's ruling in Ford v. Quebec, [1988] 2 S.C.R. 712, the National Assembly of Quebec reenacted essentially the same ban on English language signs, accompanied by an invocation of s. 33 . abstract," but they say that it is "too simplistic." 51 It is too simplistic, because it "fails to recognize the staying power of a new, judicially created policy status quo."52 By this they mean that once the Court has spoken, governments may find it expedient to leave the issue alone, thus preserving the judicial decision.

One of the two examples Morton and Knopff provide of "the staying power of the new judiciallycreated policy status quo" is the aftermath to the Morgentaler decision, ${ }^{53}$ which struck down the therapeutic abortion provisions of the Criminal Code on the ground that they offended section 7 of the Charter. The Government of Canada introduced a new bill to recriminalize abortion, but with less onerous requirements for legal therapeutic abortions. The new bill was passed by the House of Commons and then defeated in the Senate on a tie vote. ${ }^{54}$ To be sure, the status quo created by the Supreme Court of Canada (no regulation of abortion) was preserved. But this example could as easily be treated as a case of dialogue since the Government did propose a substitute law for the one struck down and very nearly succeeded in enacting it.

The other example they provide is the aftermath of the Vriend decision, ${ }^{55}$ where the Supreme Court of Canada added sexual orientation to the grounds of discrimination for which a remedy was available under Alberta's Human Rights, Citizenship and Multicultural Act. ${ }^{56}$ The Government of Alberta mused publicly about restoring the old version of the statute by invoking section 33 , but eventually decided not to do so, thus leaving the new ground of sexual orientation in the Act.$^{57}$ The authors comment that the judicial ruling had "raised the political costs of saying no to the winning minority" and the Government concluded that "the safest thing was to do nothing." ${ }^{58}$ But what does this example show? Only that it is politically difficult to directly reverse a decision of the Supreme Court of Canada on an equality issue. Is that not as it should be? Reversal is possible in a case where there is a sufficiently strong popular revulsion of the Court's ruling, and this is an exceedingly important safeguard, forcing governments to take responsibility for their decisions and avoiding the extreme forms of courtpacking and court-bashing that occur in the United States.

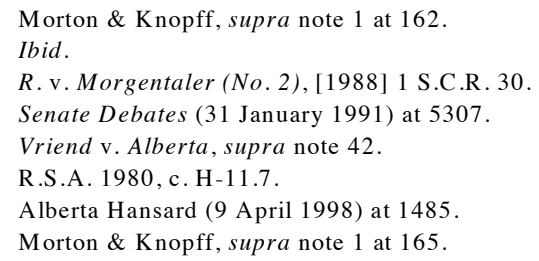


In fact, as noted earlier in this paper, the power to reverse a judicial ruling has in fact been exercised twice in Canada. It was done once by the National Assembly of Quebec, which reversed the Ford decision and restored its French-only law for commercial signs, and it was done once by the Parliament of Canada, which reversed the Daviault decision and restored the rule that intoxication is no defence to criminal offences of general intent. ${ }^{59}$ The decision of the Government of Alberta not to attempt to reverse the Vriend decision was probably based on a correct judgment that popular support was lacking for such a move.$^{60}$ The fact that the move was legally possible and was seriously examined by the Government means that the sequel to Vriend could easily be regarded as an example of dialogue rather than as an example that contradicts the dialogue idea.

In any event, Ford, Daviault and Vriend are not typical cases. In the great majority of Charter cases, there is no political impulse to directly reverse the judicial decision. Usually, the attitude of the government whose law was struck down is not one of hostility to the Court's civil libertarian concern; rather, the issue for the government is (as it was after Morgentaler) the crafting of a new law that accommodates the Court's concerns while preserving the legislative objective. A good example is provided by the Parliament of Canada's reaction to a series of decisions by the Supreme Court of Canada that ruled that surreptitious electronic surveillance by police informers wearing body packs or using hidden cameras was an unconstitutional search and seizure under section 8 of the Charter. ${ }^{61}$ In my view, this was an extravagant extension of the guarantee against unreasonable search and seizure and an unfortunate impediment to the safety and reliability of police investigations. ${ }^{62}$ What Parliament did, however, was to promptly amend the Criminal Code by providing for the issue of a warrant to authorize various forms of electronic surveillance and providing for measures to be taken without warrant in situations of emergency or danger to the police officer. ${ }^{63}$ It cannot be said, therefore, that the decisions of the Court had any longterm adverse consequences, and it is arguable that the field of electronic surveillance was in need of more regulation, which has now been provided.

\footnotetext{
59 Supra notes 49, 50.

60 Fletcher \& Howe, supra note 42 at 34,39 , report a majority of seventy-eight per cent of respondents expressing agreement with the outcome of Vriend, and note that majorities were present in all regions of the country.

61 R.v.Duarte, [1990] 1 S.C.R.30;R.v. Wiggins, [1990] 1 S.C.R 62; R. v. Wong, [1990] 3 S.C.R. 36.

62 Hogg, supra note 6 at s. 45.5(b) elaborates these criticisms.

63 Criminal Code, R.S.C. 1985, c. C-46, as am. by S.C. 1993, c. 40, s. 487.01
}

The legislative action that followed the decisions on electronic surveillance is a much more typical response to a Charter decision striking down a law than is the legislative inaction that followed the decisions in Morgentaler and Vriend. In the 1997 dialogue study, Bushell and I looked at the responses to sixty-five decisions in which laws had been struck down on Charter grounds. Of the sixty-five cases, all but thirteen elicited some response from the competent legislative body. Seven responses consisted simply of the formal repeal of the offending law, but in the remaining fortyfive cases - more than two-thirds of the total - a new law was substituted for the old law that had been struck down.

A dramatic example of the acceptance by the Supreme Court of Canada of the notion of dialogue is the Mills case ${ }^{64}$ decided after the Hogg and Bushell study. In that case, the Court upheld a new set of rules for confidentiality of records of sexual assaults that were more restrictive of the accused's right to make full answer and defence than had been stipulated in the earlier $O$ 'Connor decision. ${ }^{65}$ The Court offered the idea of dialogue as a reason for deferring to Parliament's judgment as to the appropriate balance between the accused's right to make full answer and defence and the privacy right of the complainant.

To return to the Morton-Knopff thesis, in the majority of Charter cases, the "staying power of a new judicially created policy status quo" at all. In those rare cases where government simply cannot abide the Court's interpretation of the Charter, reversal is usually legally possible, and can be accomplished politically where public opinion is particularly strong, as Ford and Daviault demonstrate. Where public opinion is less strong or is divided, government may choose to leave the decision in place, as Vriend demonstrates.

The important point about the idea of dialogue is that judicial decisions striking down laws are not necessarily the last word on the issue, and are not usually the last word on the issue. The legislative process is influenced by but is not stopped in its tracks by a Charter decision. The ultimate outcome is normally up to the legislative body. 


\section{CONCLUSION}

Yes, there has been a "Charter revolution," giving a new role to the courts in enforcing a body of guaranteed rights, which are expressed in such vague language that the courts have a great deal of choice in selecting the "correct" interpretation. And yes, there is a "Court Party," consisting of groups who have accommodated to the new reality and seek to achieve their policy goals in the courts. But the judicial decisions to which Morton and Knopff object can easily be accommodated to a notion of democracy that is not pure majoritarian decision-making, but which acknowledges that the fair treatment of individuals and minorities sometimes needs the intervention of courts. In any case, as I hope I have shown, the intervention of courts does not close down the marketplace of ideas, and a public debate usually follows any important Charter decision. That debate often increases public awareness of minority perspectives (consider for example the strong public support that now exists for same-sex rights), which in turn influences the form that any legislative response takes. Because of sections 1 and 33 of the Charter, the legislature usually has a good deal of discretion as to the appropriate response to a Charter decision, and, bearing in mind public opinion, will normally want to replace a law that has been struck down with one that accomplishes the public policy objective but is more inclusive of minorities and less intrusive of guaranteed rights.
This kind of interaction between the efforts of the Court Party, the decisions of the Courts, the debate in the public media and the ultimate response of the legislature is by no means undemocratic. The claim that judicial review under the Charter of Rights and Freedoms is "undemocratic" cannot be sustained.

\section{Peter W. Hogg}

Dean, Osgoode Hall Law School, York University, Toronto. I gratefully acknowledge the help I received from extensive comments on an earlier draft of this paper by my Osgoode colleague, Bruce Ryder, by Allison Thornton of Blake, Cassels \& Graydon LLP, and by my research assistant, Hooman Tabesh, Osgoode class of 2002.

This essay is based on the text of the thirteenth McDonald Lecture in Constitutional Studies delivered in March, 2001. 